\title{
Rektum Kanserinde Cerrahi Yönetiminin Güncel Literatür Eşliğinde İncelenmesi
}

\section{Review of Surgical Management in Rectal Cancer in The Light of Current Literature}

\author{
Esat Taylan UĞURLU ${ }^{1}{ }^{(D)}$, Ali Ulvi ÖNGÖREN ${ }^{2}$ \\ 1 Sağlık Bilimleri Üniversitesi Mehmet Akif İnan Eğitim araştırma hastanesi. Genel Cerrahi Kliniği, Şanlıurfa, TÜRKIYE \\ 2 Sağılk Bakanlığı Ankara Eğitim Araştırma Hastanesi Genel Cerrahi Kliniği, Ankara,TÜRKIYE
}

Öz.

Amaç: Rektum kanserleri yavaş seyirli, uzun süre asemptomatik olabilirken sonuçta ölümcül bir sistemik hastalık olduğu söylenebilir. Günümüzde primer tedavisi cerrahidir. Erken teșhis, ameliyat öncesi doğru evrelendirme, senkron ve metakron kolorektal kanserleri saptama ve lokal rekürrensleri tedavi edilebilir durumda tespit etme cerrahi tedavinin başarısında en önemli belirleyicilerdir. Çalışmamızda rektal. kanserlerin özellikleri ile cerrahi yaklaşımın ilkelerini güncel literatür ışığında gözden geçirerek, kliniğimizde tespit ve tedavi edilmiş rektal kanserli vakaları, etyo-patogenez, patoloji, semptomatoloji, teşhis, tedavi ve rekürrens sonuçları açısından güncel literatürlerle incelemeye çalıştık

Materyal ve metod: Sağlık Bakanlı̆ı Ankara Eğitim ve Araștırma Hastanesi 2. Genel Cerrahi Kliniğinde Aralık 1993-Aralık 1999 tarihleri arasında rektum kanseri tanısıyla ameliyat edilen 82 hastayı analiz ettik. Bu çalışmada, arşiv dosyalarından hastalara ait yaş, cinsiyet, semptom, semptom süresi, yapılan tetkik, tümörün anatomik lokalizasyonu, yapılan ameliyat, görülen komplikasyonlar, tümör evresi, postoperatif uygulanan adjuvan tedavi, hasta takipleri ve bu süre içindeki lokal nüksler ve uzak metastazlar kayıt altına alındı

Bulgular: Hastalarımızın yas ortalaması 57.7 , ve \%20'si 40 yas alındaydı. Hastaların 30 'u $(\% 36,6)$ kadın, 52 'si $(\% 63,4)$ erkek idi. Hastaların 10'u (\%12,1) akut karın tablosuyla acil olarak, 72'si $(\% 87,8)$ elektif olarak ameliyat edilmiştir. Yapılan tam kan sayımlarında hastaların \%18,2'sinde (Hemoglobin değeri $10 \mathrm{~g} / \mathrm{dl}$ alında) anemi saptanmıştı. Vakalarımızın 11 'inde $(\% 13,4)$ karaciğer metastazı mevcuttu. Rektum kanserli 82 hastanın tanı sırasındaki CEA, CA19-9 düzeyleri incelenmiştir. CEA düzeyi $60(\% 73,1)$ hastada, CA19-9 düzeyleri ise $35(\% 42,6)$ hastada yüksek bulundu. İstatistiki analizde CEA duyarlılı̆ı̆ın CA19-9 a göre daha üstün olduğu belirlendi $(P<0.01)$. Vakalarımızdaki rezektabilite oranı $\% 79,2$ 'dir. Modifiye Dukes sınıflamasına göre $A$ evresinde bir hasta (\%1,2), BI evresinde 8 hasta (\%9,7), B2 evresinde 17 hasta (\%20,7), C1 evresinde 19 hasta $(\% 23,1), \mathrm{C} 2$ evresinde 26 hasta $(\% 31,7)$ ve $D$ evresinde 11 hasta $(\% 13,4)$ tespit edilmiştir.

Sonuç: Rektum kanserlerinde erken teşhis, ameliyat öncesi doğru evrelendirme, senkron ve metakron kolorektal kanserleri saptama ve lokal rekürrensleri tedavi edilebilir durumda tespit etme cerrahi tedavinin başarısında en önemli belirleyicilerdir.Ayrıca hekim-hasta ilişkisinin ideal koşullara ulaşması ve erken teşhisin sağlanması bu hastalıkta daha başarılı sonuçların alınması için şarttır.

Anahtar Kelimeler: Rektum kanseri, Total mezorektal eksiyon, Low anterior rezeksiyon, Abdominoperineal rezeksiyon

Abstract

Background: Although rectal cancers have a slowly progressive and these cancers are asymptomatic for a long time, it can be said that they are fatal systemic disease. Today, its primary treatment is surgery. Early diagnosis, correct preoperative staging, synchronicity and determining metachronous colorectal cancers and determining local recurrences in a treatable condition are the most important determines of the success of surgical treatment. In our study, by reviewing the characteristics of rectal cancers and the principles of surgical approach in the light of the current literature, we tried to examine rectal cancer cases detected and treated in our clinic in terms of etio-pathogenesis, pathology, symptomatology, diagnosis, treatment and recurrence results in the light of current literature.

Materials and Methods: Between December 1993 and December 1999, we analyzed 82 patients who are operated on for rectal cancer in 2nd. General Surgery Clinic of Ministry of Health Ankara Training and Research Hospital. In this study, from archive files, patients' age, gender, symptom, symptom duration, examinations, anatomical location of tumor, complications, tumor stage, postoperative adjuvant treatment, patient follow-up and local recurrences and distant metastases during this period were recorded.

Results: The average age of our patients was 57.7 , and $20 \%$ were under 40 years old. $30(36,6 \%)$ of patients were female, 52 of the patients $(63,4 \%)$ were male. $10(12,1 \%)$ of the patients were operated urgently with acute abdominal pain and $72(87,8 \%)$ of the patients were operated electively. Anemia was detected in $18.2 \%$ of the patients (Hemoglobin levels below $10 \mathrm{~g} / \mathrm{dl}$ ) in the complete blood cell counts. $11(13,4 \%)$ of our cases had liver metastasis. CEA, CA19-9 levels during the diagnosis of 82 patients' who had rectal cancer were examined. CEA level was found high in $60(73,1 \%)$ patients, CA19-9 levels were found high in $35(42,6 \%)$ patients. In the statistical analysis, CEA sensitivity was identified to be superior to CA19-9. Respectability ratio of our cases was $79,2 \%$. According to the Modified Dukes classification, one patient (1.2\%) in A stage, 8 patients $(9.7 \%)$ in stage $\mathrm{B} 1,17$ patients (20.7\%) in B2 stage, 19 patients (23.1\%) in stage $\mathrm{C} 1,26$ patients (31.7\%) C2 and 11 patients (13.4\%) in $\mathrm{D}$ stage were detected.

Conclusion: In rectal cancers, early diagnosis, correct preoperative staging, synchronicity and determining metachronous colorectal cancers and determining local recurrences in a treatable condition are the most important indicatives of the success of surgical treatment. In addition, doctor - patient relationship to reach ideal conditions and ensuring the early diagnosis are essential to get successful results in this disease.

Key words: Rectal cancer, Total mesorectal excision, Low anterior resection, Abdominoperineal resection

\section{Sorumlu Yazar I \\ Corresponding Author}

Op. Dr. Esat Taylan UĞURLU

Sağlık Bilimleri Üniversitesi Mehmet Akif İnan Eğitim Araştırma Hastanesi Genel Cerrahi Kliniği Esentepe Mah. Haliliye/Şanlıurfa,63300

e-mail: esattaylanugurlu@gmail.com doktoramca_1971@hotmail.com

Tel: 05319052577

Faks: 04143186707

Geliş tarihi / Received: 26.11.2020

Kabul tarihi / Accepted: 14.12.2020

\section{DOI: 10.35440/hutfd.831965}

Çalışmamız 5-7 Haziran 2020'de Şanlıurfa'da yapılan Uluslararası Harran Sağlık Bilimleri Kongresinde sözlü sunu olarak sunulmuştur

Bu çalışma Dr.Esat Taylan UĞURLU'nun tıpta uzmanlık tezinden üretilmiştir. 


\section{Giriş}

Yirmi birinci yüzyılın başında olduğumuz şu dönemde, rektum kanseri, önemli bir tıbbi ve sosyal problem olma özelliğini sürdürmektedir. Halen tüm kolorektal kanserlerin \% 30 kadarını rektum kanseri oluşturmaktadır (1). Yüksek prevalansına rağmen rektum kanserinin optimal cerrahi, tıbbi ve radyo-onkolojik tedavisi hala tartışmalıdır (2). Rektum kanserinin tedavisinde transanal eksizyonla lokal tedavi ve abdominoperianal rezeksiyon (APR) arasında değişen çeşitli cerrahi seçenekler vardır (3). Günümüzde robotik cerrahi minimal invaziv cerrahide en yeni gelişmedir (4). Cerrahi tedaviyi destekleyen kemoterapi ve radyoterapi alanındaki gelişmelerle de hastaların daha iyi bir prognoza sahip olmaları hedeflenmektedir. İmmünoterapi denenmiş, ancak yeterli başarıyı gösterememiştir. Gastrointestinal sistemin diğer bölgelerinden gelişen kanserlere göre daha yavaş seyirlidir. Bu nedenlerden dolayı cerrahi primer tedavi seçeneğidir. Rektum cerrahisi bu yüzyılın başından beri uygulanmakta ve başarılı olmaktadır. Fakat lokal nüks oranları yüksek olarak bulunmaktadır $(1,2)$. Çalışmamızda rektal kanserlerin özellikleri ile cerrahi yaklaşımın ilkelerini güncel literatür ışığında gözden geçirerek, kliniğimizde tespit ve tedavi edilmiş rektal kanserli vakaları, etyopatogenez, patoloji, semptomatoloji, teşhis, tedavi ve rekürrens sonuçları açısından incelemeye çalıştık. Kendi bulgularımız ile literatür verilerini karşılaştııp, rektal karsinomlu hastalara cerrahi yaklaşımda özellik taşıyan konuları tartışmayı amaçladık.

\section{Materyal ve Metod}

Sağlık Bakanlığı Ankara Eğitim ve Araştırma Hastanesi 2. Genel Cerrahi Kliniğinde Aralık 1993-Aralık 1999 tarihleri arasında rektum kanseri tanısıyla ameliyat edilen 82 hastayı analiz ettik. Bu çalışmada, arşiv dosyalarından hastalara ait yaş, cinsiyet, semptom, semptom süresi, yapılan tetkik, tümörün anatomik lokalizasyonu, yapılan ameliyat, görülen komplikasyonlar, tümör evresi, postoperatif uygulanan adjuvan tedavi, hasta takipleri ve bu süre içindeki lokal nüksler ve uzak metastazlar kayıt altına alındı. Vakalarımızın \% 18.2'sine barsak temizliği için konvansiyonel yöntem uygulanmış ve bu hastalara barsak temizliği sonrası trimetoprim/sülfametaksazol (2x1 gr/gün) verilmiştir. Hastaların \% 69,5'ine barsak temizliği için Nicholl's yöntemi uygulanmış ve bu hastalarda oral antibiyotik olarak ameliyattan bir gün önce Eritromisin baz (3x1 gr/gün) verilmiştir. Acil olarak ameliyata alınan hastalara barsak temizliği yapıımamıştır. Hastaların tümüne ameliyat başlangıcından bir saat önce seftriakson 1gr. Flk. 2x1 i.v başlanmış ve operasyon sonrası 5 gün metronidazol $200 \mathrm{mg} 3 \times 1$ i.v ile kombine edilerek devam edilmiştir.

Elektif şartlarda ameliyat edilen tüm vakalara preoperatif rutin tetkikler, proktosigmoidoskopi, doku tanısı için biyopsi ve abdominopelvik Ultrasonografi (USG) yapılmış olup ay- rıca serum karsinoembriyojenik antijen (CEA), karbonhidrat antijen $\left(\mathrm{CA}_{19-9}\right)$ düzeylerine bakılmıştır. Preoperatif doğru evrelendirme yapabilmek için, kırk vakaya abdominopelvik CT ve otuz vakaya endorektal USG yapılmıştır. Tüm elektif vakaların ameliyat öncesi histopatolojik tanıları belirlenmiştir. Hiçbir hastaya preoperatif radyoterapi ve kemoterapi uygulanmamıştır. Tümörlerin evrelendirilmesi Modifıye Dukes sınıflamasına göre patoloji raporları yorumlanarak yapılmıştır. Bu çalışmada, anal vergeden 0-5 $\mathrm{cm}$ arasında olan bölge alt rektum, $6-10 \mathrm{~cm}$ arası orta rektum, 11-15 arası üst rektum olarak değerlendirildi. Hastalar ilk iki yıl, üç ayda bir daha sonra altı ayda bir kontrollere çağrımışlardır. Periyodik kontrollerde, hastaların şikayetleri, fizik muayeneleri, rutin biyokimya tetkikleri, hemogram, biyolojik tümör markerları ve akciğer grafilerine bakımıştır. Abdominopelvik USG, ilk iki yıl, 3-4 ayda bir, daha sonra 6 ayda bir tekrarlanmıştır. Takiplerde erken ve geç komplikasyonlar, hastalıksız geçen süre, lokal nüks ve metastaz durumları belirlenmiştir.

\section{İstatistiksel Analiz}

İstatistiksel analizlerde SPSS (Chicago, llinois) 10.0 versiyonu kullanıldı. Retrospektif olarak gerçekleştirilen bu çaIışmada tanımlayıcı bulgular için yüzdelik hesaplamalar, ortanca ve standart sapma kullanıldı. Analizlerde Chi-Square, $T$ testi kullanıldı. İstatistiksel anlamlı değer $P<0.05$ olarak kabul edildi.

\section{Bulgular}

Hastalarımızın yaş ortalaması 57.7 , ve $\% 20$ 'si 40 yaş altındaydı. Hastaların 30'u $(\% 36,6)$ kadın, 52'si $(\% 63,4)$ erkek idi. Hastaların 10'u (\%12,1) akut karın tablosuyla acil olarak, 72 'si $(\% 87,8)$ elektif olarak ameliyat edilmiştir. Vakalarımızın başvuru semptomları Tablo 1 de özetlenmiştir. Yapılan tam kan sayımlarında hastaların \%18,2'sinde (Hemoglobin $10 \mathrm{~g} / \mathrm{dl}$ altında) anemi saptanmıştır.

Tablo 1. Hastalara ait semptomlar

\begin{tabular}{|l|l|l|}
\hline Semptomlar & Vaka Sayısı (n) & Yüzde (\%) \\
\hline Rektal kanama & 50 & 60.9 \\
\hline Kilo kaybı & 35 & 42.6 \\
\hline Rektal ağrı & 25 & 30.4 \\
\hline Defekasyondan sonra boşalamama hissi & 20 & 24.3 \\
\hline Karın ağıIsı & 20 & 24.3 \\
\hline Anemi & 15 & 18.2 \\
\hline Ishal & 10 & 12.1 \\
\hline Akut karın & 10 & 12.1 \\
\hline
\end{tabular}

Radyolojik ve endoskopik görüntüleme yöntemleri ile tümörün, rektumdaki lokalizasyonları Tablo 2 de gösterilmiştir. Vakalarımızın 11'inde $(\% 13,4)$ karaciğer metastazı mevcuttu. Rektum kanserli 82 hastanın tanı sırasındaki CEA, CA $_{19-9}$ düzeyleri incelenmişstir. CEA düzeyi 60 $(\% 73,1)$ hastada, $\mathrm{CA}_{19-9}$ düzeyleri ise, $35(\% 42,6)$ hastada 
yüksek bulundu. İstatistiki analizde CEA duyarlılığının $\mathrm{CA}_{19-9}$ a göre daha üstün olduğu belirlendi $(P<0.01)$. Vakalarımızdaki rezektabilite oranı \%79,2'dir. Yani 65 vakaya küratif veya palyatif rezeksiyon yapılmıştır. 17 vaka $(\% 20,7)$ nonrezektabl olarak değerlendirilmiş ve bunların 14'üne sigmoid kolostomi, 3'üne transvers loop kolostomi yapılmıştır.

Tablo 2. Tümörün rektumdaki lokalizasyonu

\begin{tabular}{|l|l|l|}
\hline Tümörün anal verge'den uzaklığı (cm) & Vaka sayısı (n) & Yüzde (\%) \\
\hline $0-5$ & 40 & 48.7 \\
\hline $6-10$ & 27 & 32.9 \\
\hline $11-15$ & 15 & 18.2 \\
\hline
\end{tabular}

Karaciğer metastazı saptanan 11 vakanın üçüne operasyon esnasında metastazektomi yapıldı. Acil şartlarda ameliyata alınan vakalarımızın 8'inde intestinal obstrüksivon, 2'sinde tümör perforasyonu mevcuttu. İntestinal obstrüksiyonu olan hastaların 2'sine transvers loop kolostomi, 6'sına sigmoid kolostomi yapıldı. Perforasyon mevcut olan 2 hastanın birine perforasyon bölgesine primersütür+transvers loop kolostomi, diğerine de perforasyon bölgesine primer sütür + sigmoid kolostomi yapılmıştır. Lezyonun evresi ve yapılan ameliyat dikkate alarak 61 vakadaki müdahaleyi küratif olarak değerlendirdik. 4 vakadaki ameliyat palyatif amaçlı rezeksiyondur ve 17 vakada ise nonrezektabl kabul edilerek palyatif kolostomi yapılmıştır, Palyatif rezeksiyon yapılan 4 vakaya abdominoperineal rezeksiyon ameliyatı uygulanmıştır. Küratif amaçla yapılan ameliyatlardan 34'ünü abdominoperineal rezeksiyon, 26'sını low-anterior rezeksiyon, l'ini de lokal eksizyon oluşturmaktadır. Tümör, low-anterior (LAR) yapılan 26 vakanın 20'sinde orta rektumda 5'inde üst rektumda idi. 5 vakada anostomozlar stapler tekniği ile yapılmış olup bunlardan bir vakada postoperatif birinci haftada anostomoz yetmezliği nedeniyle operasyon abdominoperineal (APR) rezeksiyona çevrilmiştir. Tümör, abdominoperineal rezeksiyon yapılan 30 vakada alt, 8 vakada orta rektumda lokalize idi. Palyatif olarak kolostomi açılan 17 hastanın 10'unda tümör alt rektumda, 4'ü orta rektumda, 3'ü üst rektumda yerleşmişti. APR + TAH (Total abdominal histrektomi) + BSO (Bilateral salpengo ooferektmi) yapılan iki hastada vajen arka duvarına yapışıklık nedeniyle, vajen arka duvarı rezeksiyonu yapımıştır. Serimizde hastanede kalış süresi 2-36 gün arasında ve ortalama 21 gündür. Yapılan ameliyatlar Tablo 3'te gösterilmiştir. Vakalarımızda peroperatif mortalite olmadı. Erken postoperatif mortalite \%4,8'dir. Tümör histopatolojik tanıları Tablo 4' te gösterilmiştir. Rektoskopide eksofitik sert kitle olarak tespit edilen bir vakada transanal lokal eksizyon yapılmışıı. Histopatolojik tanısı adenokarsinomdur. Serimizde preoperatif histopatolojik değerlendirmede tümörün tipine ait yanılgı \%4.8 dir. Modifiye Dukes sınıflamasına göre $\mathrm{A}$ evresinde bir hasta $(\% 1,2)$, Bı evresinde 8 hasta $(\% 9,7), B_{2}$ evresinde 17 hasta $(\% 20,7)$, Cl evresinde
19 hasta $(\% 23,1), C_{2}$ evresinde 26 hasta $(\% 31,7)$ ve $D$ evresinde 11 hasta $(\% 13,4)$ tespit edilmiştir.

Tablo 3. Tümörün yerleşim yerine göre ameliyat tekniği

\begin{tabular}{|l|l|l|l|l|}
\hline Ameliyatlar & Alt & Orta & Üst & Toplam \\
\hline LAR & - & 14 & 7 & 21 \\
\hline LAR+BSO & - & 4 & 1 & 5 \\
\hline APR & 24 & 2 & - & 26 \\
\hline APR+BSO & 3 & 1 & 4 & 4 \\
\hline APR+TAH+BSO & 6 & 2 & - & 8 \\
\hline Transvers Kolostomi & - & - & 3 & 3 \\
\hline Sigmoid Kolostomi & 7 & 7 & - & 14 \\
\hline Lokal Eksizyon & 1 & $*$ & & 1 \\
\hline
\end{tabular}

(LAR:Low anterior rezeksiyon,APR:Abdomino perineal rezeksiyon,TAH:Total abdominal histerektomi,BSO:Bilateral salpengo ooferektomi)

Tablo 4. Tümör histopatolojik tanıları

\begin{tabular}{|l|l|l|l|l|l|}
\hline \multirow{2}{*}{ Histopatolojik tanı } & \multicolumn{2}{|l|}{ Differansiasyon } & $\begin{array}{l}\text { Vaka } \\
\text { sayısı }\end{array}$ & Yüzde \\
\cline { 2 - 7 } & Az & Orta & Kötü & (n) & (\%) \\
\hline Adenokarsinom & 1 & 41 & 12 & 64 & 78.0 \\
\hline Müsinöz adenokarsinom & 2 & 7 & 2 & 11 & 13.4 \\
\hline Taşlı yüzük hücreli karsinom & 1 & 2 & 1 & 4 & 4.8 \\
\hline $\begin{array}{l}\text { Nöroendokrin diferansiasyon gös- } \\
\text { teren adenokarsinom }\end{array}$ & & & & 2 & 2.4 \\
\hline Karsinoid tümör & - & - & - & 1 & 1.2 \\
\hline
\end{tabular}

Tablo 5. ìki yıllık sağkalım oranları

\begin{tabular}{|l|l|}
\hline Evre & iki Yıllık Sağkalım Oranı (\%) \\
\hline A & 100 \\
\hline B & 90 \\
\hline C & 58.8 \\
\hline D & 0 \\
\hline
\end{tabular}

Uzak organ metastazı olan tümörler D evresi olarak değerlendirildi. Vakalarımızdan 20 hastada $(\% 24,3)$ yara enfeksiyonu görülmüştür. Operatif morbiditemiz bir hastada üreter, üç hastada üretra yaralanmasıyla $\% 4,8$ 'dir. Üriner inkontinans üç hastada gelişti. Cerrahi tedaviye ilave olarak kırk hastaya $(\% 48,7)$ postoperatif kemoterapi, 28 hastaya $(\% 34,1)$ kemoterapi + radyoterapi yapılmıştır. Adjuvan tedaviler için medikal ve radyasyon onkolojisi kliniklerinin görüşleri alınmıştır. Küratif rezeksiyonlu 61 hastanın 16'sında $(\% 26,2)$ lokal rekürrens görülmüştür. Vakalarımızda en erken rekürrens beşinci ayda görülmüştür. Low anterior rezeksiyon yapılan 7 hastada, APR yapılan 9 hastada lokal rekürrens görülmüştür. Lokal rekürrensin ortalama görülme süresi 14 aydı. Ortalama takip süremiz 28 aydır. İki yıl gibi kısa bir süre için genel sürvival oranımız $\% 60$ 'dır. İki yıllık sağ kalım oranlarımız Tablo 5' te gösterilmiş̧tir. 


\section{Tartışma}

Serimizde 82 hastanın yaş ortalaması 57.7 idi. Mayo Kliniği'nin yakın zaman içindeki tecrübelerine göre rektum kanserlerinin tanı yaşı 67'dir (ortalama 23-99) (2) olgularımızda erkek/kadın oranı 1,73 olarak erkekler aleyhine yüksek bulunmuştur. Serimizde ailevi geçişi düşündürecek vaka saptanmamıştır. Çalışmamızda rektal kanama şikâyeti literatüre göre iki katı sıklıkta, genellikle literatürde ikinci sırada görülen ishal ve müküslü akıntı altıncı sırada ve nadir görülen rektal ağrı üçüncü sırada yer almaktadır (5). Bu duruma hastaların bazı semptomları önemsememeleri ya da hemoroid gibi başka sebeplere bağlanmış olmaları nedenler arasında düşünülebilir. Rektum kanserlerinde tıkanma, perforasyon ya da kanama nedeniyle acil ameliyat gerekebilir. Tıkayıcı rektum kanseri en sık acil ameliyat nedenidir. Biz de olgularımızda \%9,7 oranında intestinal obstrüksiyona \%2,4 oranında perforasyona rastla$\operatorname{dık}(6)$.

Hastalarda semptomların başlangıcından itibaren cerrahi tedaviye kadar geçen süre oldukça uzundur. Sadece 30 hastanın $(\% 36,5)$ semptomları belirdikten sonraki ilk üç ayda ameliyat edilmesi, A evresinde bir hastanın bulunuşu ve vakaların ancak \%30,4'ünün $B$ evresinde ameliyat edilmiş olması hastaların doktora geç başvurmuş olmalarına veya başvurdukları merkezlerde titizlikle muayene ve tetkik edilmemiş olmalarına bağlanabilir. Vakalarımızı global olarak değerlendirdiğimizde, tanıya kadar geçen süre ortalama 6,3 aydır. Bir seride vakaların \%34,1'i alt rektumda yerleştiği bildirilmiştir (7). Vakalarımızın \%48,7'sinin alt rektuma yerleşmiş olması ve değişik yazarlarca rektum kanserinin \%50-70 oranında rektal tuşe ile tespit edilebildiğinin belirtilmesi basit muayene yöntemlerinin önemini koruduğunu göstermektedir (8).

Non-rezektabl rektum kanseri tanısı multidisipliner bir ekip tarafından konulabilir. Tüm rektum kanserlerinin \% 1015 'ini oluştururlar. Bizim vakalarımızdaki rezektabilite oranı $\% 79,2$ olarak bulunmuştur. Robotik cerrahi özellikle dar pelvislerde hassas diseksiyon imkanı tanıdığından rektum kanseri cerrahi tedavisinde daha iyi klinik sonuçlar alma potansiyeline sahiptir. Tüm rektum kanserlerinin \% 1015 'ini oluştururlar. Total mezorektal rezeksiyonun (R-TME) laparaskopi ya da açık cerrahiye daha üstün olduğunu gösteren güçlü kanıt olmamakla beraber güncel veriler RTME'nin teknik zorluklar içeren subgruplarda (obez,erkek hastalar) daha iyi sonuçlar alınabilineceğini göstermektedir (4). Bir çalışmada rektum kanserlerinde robotik aşağı anterior rezeksiyon daha uzun operasyon süresi ve daha az kan kaybı ile laparaskopik aşağı anterior rezeksiyona benzer şekilde etkin ve güvenli bir şekilde uygulanabileceği bildirilmiştir (9). Radikal operasyon için mezorektumun tamamen çıkarılması önemlidir. Heald ve Ryall, mezorektumun tamamen çıkarıldığı erken evre rektum kanserli 50 hastada sfinkter koruyucu rezeksiyondan sonra lokal rekürrens gö- rülmediğini bildirmişlerdir (10). Biz küratif rezeksiyon uyguladığımız 61 vakamızda mezorektumu tamamen çıkardık ve konvansiyonel rektum rezeksiyonu uyguladık. Patrick Lee ve arkadaşlarının 38 hastalık çalışmalarında endorektal USG'nin doğruluk derecesini \%79 olarak bildirmişlerdir (11). Biz 30 vakaya endorektal USG yaptırabildik. Bu vakalardaki doğruluk derecesi \% 66,6'dır.

Tümörün alt sınırı ile anal verge arasındaki mesafe ve komşu organ tutulumu cerrahi prosedür seçimini belirlemektedir. Biz low anterior rezeksiyon ameliyatın $5 \mathrm{~cm}$ ve üzerinde olan tümörlere uygulamaya çalıștık. Tümörü distalde en az $2 \mathrm{~cm}$ makroskopik sağlam alan bırakarak çıkardık. Bizim $5 \mathrm{~cm}$ altındaki vakalara APR yapmamızdaki en önemli neden bu seviyenin altında manuel anostomozun zorluğudur. Çalışmalarda 2 cm'den daha az kenar bırakılan hastaların \%25-30'unda aşağı halkanın histolojik muayenesinde rezidüel hastalık negatif olsa bile anostomoz hattında rekürrens bildirilmektedir $(11,12)$. Biz distal kenarı anal verge'den $5 \mathrm{~cm}$ 'den daha yukarıda olan 5 hastaya APR yaptık. Bunlardan 3 vakada vajen arka duvarına, 2 vakada da prostata neoplastik natürde yapışıklık saptanmıştı. Rektum kanserli hastaların \%85 ile 90'ınd low-anterior rezeksiyon veya APR'dan biri tercih edilir (13). Deneyimimiz rekürrensin uygulanan cerrahi teknikten çok tümörün evresine, ekstraparietal ve mezorektal infiltrasyonun varlığına, lenfanjite ve tümör diferansiyasyonunun derecesi gibi neoplazmın belli özelliklerine bağlı olduğunu ortaya koymaktadır. Ayrıca perinöral invazyonun lokal rekürrens, venöz invazyonun organ metastazı yönünden prognostik faktör oldukları bildirilmekte ve perinöral invazyon saptanan tümörlerde genişletilmiş cerrahi savunulmaktadır (14). Transanal lokal eksizyon adenomlar, karsinoidler ve anal girimden itibaren $8 \mathrm{~cm}$ 'ye kadar olan erken evre rektal kanserler için uygundur. Bazen $8 \mathrm{~cm}$ 'den daha proksimaldeki tümörlerin çıkarılması da mümkün olmaktadır. Transanal endoskopik mikrocerrahi (TEM) eski ve yeni arasındaki eşsiz bir harmanlamayı temsil ediyor. Çoğu adenomda boyu, yerleşim yeri ve çevresel tutulum derecesi ne olursa olsun TEM yöntemi ile çıkarılabilir. Malign lezyonlar için TEM yöntemi uygulanacaksa uygun hasta seçimi yapılmalıdır (Lezyon rektal duvara yüzeyel penetrasyonu, perinöral ve lenfovasküler invazyonu olmaması gibi) (15). En sık görülen intraoperatif komplikasyonun (\%3) presakral kanama olduğu ve postoperatif komplikasyonların tamamının oranının \%50,2 gibi yüksek olduğu bildirilmiştir. Rektum kanseri ameliyatlarından sonra mortalite dramatik bir şekilde düşerken, morbidite oranı şaşılacak şekilde \%21-76 arası değişen morbidite oranı bildirilmiştir (2). Rektum kanseri nedeniyle rezeksiyon sonrası ölümlerin \%2537'sinden pelvik sepsis, intrapelvik apse ve anastomoz kaçağı şeklinde gözlenebilen septik komplikasyonlar sorumludur. İlk 30 gün içindeki mortalitenin de en önemli sebebi septik komplikasyonlardır (6). Enfeksiyon sistemik, yara ve 
üriner enfeksiyon şeklinde olabilir. Olgularımızda karşılaştığımız yara enfeksiyonu \%24,3'dür ve yüksektir. Bunda olgularımızın \% 12'sini acil olarak ameliyata aldığımızdan barsak temizliği yapamamamı, \%18,2'sine ise oral antibiyotik profilaksisi olarak anaerob bakterilere etkisizliği saptanan trimetoprim/sülfametaksazol'ü kullanmamız olumsuz etkenlerdir. Mekanik bağırsak temizliğine rağmen kolorektal cerrahide anatomoz kaçak oranı $\% 4-5$, yara yeri enfeksiyonu \%8-10 oranında görülmektedir. Contant ve ark.'nın yaptıkları ve 1354 hastayı içeren randomize bir çaış̧mada mekanik barsak temizliği yapılan ve yapılmayan hastalar arasında anastomoz kaçağı, yara yeri enfeksiyonu, mortalite ve hastanede yatı̧ süresi arasında fark saptanmamıştır(16).

Literatürde standart rektum rezeksiyonundan sonra \% 2,7 oranında mesane yaralanması, $\% 2$ üretra yaralanması bildirmektedirler (17). Bizde daha önce belirttiğimiz gibi 1 üreter $(\% 1,2), 3$ üretra $(\% 3,6)$ yaralanması olmuştur. En sık görülen komplikasyonlar ürolojik olanlardır. Bir çalışmada üriner retansiyon oranı $\% 22,5$ ve üriner enfeksiyon oranı $\% 16$ olarak bildirilmiştir. Vakalarımızda rutin olarak idrar sondasını 7-10 gün süreyle yerinde bıraktık. APR yapılan 3 vakada üriner inkontinans görülmüştür. Sadece APR yapılan vakaları değerlendirirsek, üriner ikontinans oranı $\% 7,8$ 'dir. Bizim serimizde seksüel fonksiyon tam kaybı iki vaka $(\% 2,4)$ idi. Bu oranı Enker \%13 olarak bildirmektedir (17). Bizim oranımızın oldukça düşük olmasının nedenini anamnezin düzgün alınmayışına, kaydedilmeyişine, ayrıca hastaların seksüel konularda doktoru ile kontak kurmayışına bağlamaktayız.

Rektum kanserlerinin \%98'i adenokarsinomdur. Bunların $\% 15$ 'i müsinöz adenokarsinomlardır $(11,18)$. Olgularımızda adenokarsinom oranı \%96,2 olup literatüre yakındır. Müsinoz adenokarsinoma oranı $\% 13,4$, taşlı yüzük hücreli adenokarsinom \%4,8, nöroendokrin diferansiasyon gösteren adenokarsinom oranı $\% 2,4$ 'dür. Karsinoid tümörlerin, kolon ve rektum tümörleri içinde $\% 0,1$ oranında görüldüğü bildirilmektedir Genç hastalarda kolorektal kanserler ile ilgili yapılmış çalışmalarda müsinöz tümör oranı ve kötü diferansiye tümör oranı yüksek olarak belirtilmiştir(19).Bizim vakalarımı içinde karsinoid tümör oranı $\% 1,2$ 'dir. Modifiye Dukes histopatolojik sınıflamasına göre $A$ evresinde 1 vakamız $(\% 1,2)$ varken $D$ evresinde $11(\% 13,4)$ hastamız mevcuttur. Literatürde A evresinde \% 5,3-22.5, D evresinde $\% 10-11$ oranları bildirilmektedir. A evresindeki vakamızın bir tane oluşu $D$ evresindeki oranların literatüre göre yüksek oluşu hastaların geç başvurduğunu veya hekimler tarafından basit şikayetlerin atlandığını düşündürmektedir. $B$ ve $C$ evresi oranlan literatür ile uyumludur. Günümüzde rektum kanseri için, en çok kabul gören evreleme sistemi TNM sınıflamasıdır.1987 'de kolorektal kanserler için TNM sınıflama sistemi ortaya konulmuş olup 2002 'de güncellenmiştir.
Karaciğer, kolorektal kanserde en sık metastaz yeridir. Kolorektal kanserli hastaların yaklaşık olarak \%50?sinde karaciğer metastazı gelişir. Kolorektal kanserin izole karaciğer metastazlarının güncel standart tedavi yöntemi cerrahidir. Karaciğer metastazlarının rezeksiyonu sonrası 5-yıIık sağkalım oranları \%16-74 arasında değişmektedir. Hastaların yaklaşık olarak \%50'sinde rezeksiyon sonrası 2 yıl içinde rekürrens gelişmektedir. Kolorektal kanser tanılı, rezeksiyona uygun karaciğer metastazı ı hastalarda, tek başına cerrahiye kıyasla, perioperatif uygulanan kemoterapi, hastalıksız sağkalım avantajı sağlamaktadır. Başlangıçta, karaciğer metastazları rezeksiyona uygun olmayan hastalarda, daha güçlü kemoterapi rejimleri ve etkili hedefe yönelik ajanların kullanımı sayesinde, yanıt oranlarında ve rezeksiyon oranlarında artış meydana gelmiştir.(20). Ne yazık ki, rekürren kolorektal kanserden ölen hastalarda, genellikle karaciğer ve akciğer rekürrensi erken evrede saptansa bile hastada cerrahi rezeksiyon yapılamayacak tarzda multipl alan tutulumu mevcuttur. Küratif rezeksiyondan sonra takip ettiğimiz vakalarda $\% 26,2$ oranında Lokal rekürrens saptadık. Küratif rezeksiyondan sonra \%11,1 oranında karaciğer metastazı saptadık ve bu metastaz vakalarında lokal rekürrens de mevcuttu. B1 evresinde $\% 1,2$, B2 evresinde \%6,0, C1 evresinde \%3,6, C2 evresinde $\% 7,3$ ve $D$ evresinde $\% 1,2$ oranında lokal rekürrens saptadık ve bu oranlar literatürle oldukça paraleldir.

Ince kesitli Magnetik Rezonans (MR) görüntüleme teknikleri, düşük manyetik alan sistemlerinde bile tümör evrelemesinin ve pozitif çevresel rezeksiyon sınırı tahminlerinin geliştirilmesi için kullanılabilir (21). Endorektal Ultrasonografi (ERUS), BT ve MR görüntüleme sonuçlarının doğruluğunu kıyaslayan çok sayıda çalışmaya göre rektum kanserinde T evrelemesi açısından en üstün yöntemin ERUS olduğu anlaşılmaktadır. ERUS'un doğruluğu \% 80-95 arasında iken BT \% 65-75, MR görüntüleme \% 75-85 ve rektal tuşe \% 62 gibi oranlara sahiptir (1).

Rektum kanserli 82 hastamızda tanıda CEA duyarlılığı $\% 73,1$, CA19-9 duyarlıı̆̆ \%42,6 olarak bulunmuştur. Yine çalışmamızda remisyonda CEA duyarlıığı \%95,6 ve CA19-9 duyarlılığı \%86,9 olarak bulunmuştur. Rekürrens vakalarımızda bu oranlar sırasıyla $\% 86,9$ ve $\% 65,2$ 'dir. 2019 yılında yayınlanan bir çalışmada kolorektal karsinom tanısı için CEA'nın duyarlııı oranı \%44,8-47,4, özgüllük oranı \%88,2-90,2,CA19-9'un duyarlılık oranı $\% 20,3-31,8$, özgüllük oranı \%91,5-94 olarak bildirilmiştir (22).

Kolorektal kanserde hastalık evresi ile CEA duyarılığı önemli oranda değişiklik göstermektedir. Bizim serimizde bir hasta evre A iken B evresindeki hastalarımızda CEA duyarlıı̆ı \%64 idi. Birçok çalışmada erken evre (evre A ve B) hastalığı olanlarda bu oranın \%40-45'e kadar düştüğü bildirilmektedir. Bu fark bizim evre $\mathrm{A}$ hastamızın bir oluşundan kaynaklanabilir (23).

Preoperatif kombine tedavi (neoadjuvan KRT) aldıktan 
sonra rezeksiyon yapılan rektal kanserli hastalar için postoperatif KT verilmesinin yararlı olup olmadığı tarış̧ımakta olan bir konudur. Bu konuya odaklanmış bir çalışmada araştırmacılar, lokal ileri rektum kanserli hastalarda faz 2 çalışması gerçekleştirdiler (24). Randomize olmayan bu çalışmada postoperatif kemoterapi 5 yıllık sağkalımı \% 52 'den \%84'e, nükssüz sağ kalımı \% 48'den \%74'e çıkardı. Çalışmamızda cerrahi tedaviye ilave olarak kırk hastaya $(\% 48,7)$ postoperatif kemoterapi, 28 hastaya $(\% 34,1)$ kemoterapi + radyoterapi yapılmıştır.

On dört çalışmanın yer aldığı bir metanalizde preoperatif RT ve cerrahi kombinasyonu, tek başına cerrahi ile karşılaştııılıı̆ında 5 yıllık genel mortaliteyi, ("odds ratio" [OR] 0.84; 95\% "confidence interval" [Cl], 0.72-0.98; $\mathrm{p}=.03$ ), kansere özgü mortalite oranını (OR, $0.71 ; 95 \% \mathrm{Cl}, 0.61$ $0.82 ; \mathrm{P}<.001)$ ve lokal nüks oranını $(\mathrm{OR}, 0.49 ; 95 \% \mathrm{Cl}$, $0.38-0.62 ; \mathrm{P}<.001$ ) anlamlı olarak düşürdü. Bu metaanaliz, yalnız başına cerrahi ile karşılaştıııldığında preoperatif $R T$ ve cerrahi kombinasyonunun lokal kontrol ve genel sağ kaıımı önemli ölçüde artırdığını göstermiştir (25).

Evre 0 rektum kanserlerinde beş yıllık sağ kalım \%100 iken evre I de $\% 90$ civarındadır. Evre II tümörlerde $\% 60-75$, evre III tümörlerde de \%35-45 beş yıllık sağ kalım beklentisi vardır. Evre IV hastalıkta beş yıl yaşayan hasta oranı \%5-20'dir (26). Vaka grubumuzda süremiz yetersiz olduğundan 5 yıllık sürvival veremiyoruz. İki yıllık sağ kalım oranlarımız şöyledir; Evre A için \% 100, evre B için 90, evre $\mathrm{C}$ için $\% 58,8$, evre $\mathrm{D}$ için $\% 0$ dır. Ortalama takip süremiz 28 aydır.

On dört çalışmanın yer aldığı bir metanalizde preoperatif RT ve cerrahi kombinasyonu, tek başına cerrahi ile karşılaştıııldı̆ında 5 yıllık genel mortaliteyi, ("odds ratio" [OR] 0.84; 95\% "confidence interval" [Cl], 0.72-0.98; $p=.03$ ), kansere özgü mortalite oranını (OR, $0.71 ; 95 \% \mathrm{Cl}, 0.61$ $0.82 ; \mathrm{P}<.001)$ ve lokal nüks oranını $(\mathrm{OR}, 0.49 ; 95 \% \mathrm{Cl}$, $0.38-0.62 ; P<.001)$ anlamlı olarak düşürdü. Bu metaanaliz, yalnız başına cerrahi ile karşılaştıııldığında preoperatif RT ve cerrahi kombinasyonunun lokal kontrol ve genel sağ kaıımı önemli ölçüde artırdığını göstermiştir (25).

Sonuç olarak rektum kanserlerinin yavaş seyirli, uzun süre asemptomatik seyreden ölümcül sistemik bir hastalık olduğu söylenebilir. Günümüzde primer tedavisinin cerrahi olduğu herkes tarafından kabul görmektedir. Erken teşhis, ameliyat öncesi doğru evrelendirme, senkron ve metakron kolorektal kanserleri saptama ve lokal rekürrensleri tedavi edilebilir durumda tespit etme cerrahi tedavinin başarısında en önemli belirleyicilerdir. Ayrıca hekim, hasta ilişkisinin ideal koşullara ulaşması ve erken teşhisin sağlanması bu hastalıkta daha başarıı sonuçların alınması için şarttır.

Etik onam: Bu çalışmamız 1995-1999 tarihleri arasında hazırladığımız uzmanlık tezimizden türetilmiştir. Tezimiz o tarihte Sağıı Bakanlığımızın etik kurulu tarafından onaylanmış ve 1999 tarihinde uzmanlık bitiminde yine bakanlığımızın belirlediği kurul tarafından tasdik edilmiş ve kabul görmüştür

\section{Kaynaklar}

1. Dalal KM, Bleday R. Maingot Abdominal Operasyonlar. Nobel Tıp Kitabevleri, İstanbul;2008:693-725

2. Heppel JP, McConnel EJ, Schild SE. Mayo Kliniği Gastrointestinal Sistem Cerrahisi. Nobel Tıp Kitabevleri, 2004, İstanbul: 569-588

3. Shelton AA, WongWD, Güncel Cerrahi Tedavi.Avrupa Tıp LTD.STI.Yayınları 2001, İstanbul:217-239

4. Burak KB, Asoğlu O. Rektum kanseri cerrahi tedavisinde robotik cerrahinin güncel durumu. Altıntoprak $F$, editör.Robotşk Cerrahi: Teknik, Ulusal Deneyimler ve Güncel Literatür Sonuçları. 1. Baskı. Ankara: Türkiye Klinikleri; 2019;60-66.

5. Cerman, L.: Colonandrectalsurgery. 2. baskı, J.B. LippincottCompany Pennsylvania, 1989, 465-469.

6. Karman N, Doğan L, Özaslan C, Atalay C, Yılmaz KB, Altınok M. Rektum kanseriameliyatları sonrası pelvik septik komplikasyonlar. TurkishJournalofSurgery.2008;24(3):125-130

7. Ross A, Rusnak C, Weinerman B, Kuechler $P$, Hayashi A, MacLachlan $G$, et al. Recurrence and survival after surgical management of rectal cancer. Am J Surg. 1999;177(5):392-5.

8. Sözüer E,Dağlı AS, Yılmaz C, Yersiz H, Torun, R. Kolon ve rectum kanserli 34 vakanın incelenmesi. Şişli Etfal Hastanesi Tıp Bülteni 1990;2: 55-64.

9. Ladenson JH, McDonald JM, Landt M, Schwartz MK. (Washington University Case Conference). Colorectal carcinoma and carcinoembryonic antigen (CEA). Clin Chem. 1980;26(8):1213-20.

10. Heald RJ, Ryall RD. Recurrence and survival after total mesorectal excision for rectal cancer. Lancet. 1986;28;1(8496):1479-82.

11. Lee $P$, Oyama K, Homer L, Sullivan E. Effects of endorectal ultrasonography in the surgical management of rectal adenomas and carcinomas. Am J Surg. 1999;177(5):388-91

12. Moriya Y, Hojo K, Sawada T, Koyama Y. Significance of lateral node dissection for advanced rectal carcinoma at or below the peritoneal reflection. Dis Colon Rectum. 1989;32(4):307-15

13. Helmond JH, Beart RW. Kolon ve Rektum Cerrahisinde GÜNCEL TEDAVI, Avrupa Tıp Kitapçılık LTD.ŞTi. Bilim Yayınları- 51, İstanbul,2006:177-184

14. Fegiz G, Indinnimeo M, Gozzo P, Del Grande E, Cataldi S, Brozzetti S. Low rectal cancer--what is the choice? Dis Colon Rectum. 1994;37(2 Suppl):S35-41.

15. HuntSR,SaclaridesTJ.Kolon ve Rektum Cerrahisi/ Anorektal Ameliyatlar. İstanbul Medikal Yayıncılık ÇEVIRI ESERLERI dizisi, 1. baskı İstanbul, 2015:193-211

16. Seyfi E,Kavlakoğlu B,Sözen S,Yazar MF,Özkan Z. Elektif kolorektal cerrahi öncesinde mekanik bağırsak temizliği gerekli midir? Prospektif, randomize ve kontrollü bir çalışma.turkish Journal of Surgery. 2012;28(12):084-087

17. EnkerWE, Pilipshen SJ, Heilweil ML, Stearns MW, Janov AJ, Hertz $\mathrm{RE}$, Sternberg SS. Enblocpelviclymphadenectomyandsphincterpreservation in thesurgicalmanagement of rectalcancer. Ann Surg.1986;203(4): 426-433

18. Hojo K, Sawada T, Moriya Y. An analysis of survivalandvoiding, sexualfunctionafterwideiliopelviclymphadenectomy. Dis. ColonRectum 1989; 32(2):131-136

19.Özdemir Y,Sücüllü I,Filiz Aí,Yücel E,Karagöz B,Ersöz $N$ ve ark. Genç Hastalarda Kolorektal Kanserlerin Klinik ve Patolojik Özelliklerinin Değerlendirilmesi.Kolon Rektum Hast. Derg.2009;19(4):172-177

20. Ünek I.T. Kolorektal Kanserli Hastalarda Karaciğer Metastazlarına yaklaşım. Türkiye Klinikleri Tıbbi Onkoloji-Özel Konular.2018;8(1):24-37 21. Sönmez DY, Peker E, Kiremitçi S, Kuzu, Erden A, Kuzu A. Preoperatif Rektum Kanseri Evrelemesinde MR Görüntülemenin Doğruluğu. 
Ankara Üniversitesi Tıp Fakültesi Mecmuası. 2016;69(3): 173-179

22. Peng Q, Shen $Y$, Lin $K$, Zou L, Shen $Y$, Zhu Y. Identification of microRNA-92a and the related combination biomarkers as promising substrates in predicting risk, recurrence and poor survival of colorectal cancer. JCancer. 2019;10(14):3154-3171

23. Folkesson J, Birgisson H, Pahlman L, Cedermark B, Glimelius B, Gunnarsson U. SwedishRectalCancer Trial: longlastingbenefitsfromradiotherapy on survivalandlocalrecurrence rate. J ClinOncol 2005;23(24):5644-50.

24. Yavuz A, Nasirov M, BüyükkasapÇ,SalmanB,BedirliA.Rektum Kanseri Nedeniyle Robotik ve Laparaskopik Aşağı Anterior Rezeksiyon Yapılan Hastaların Sonuçlarının Karşılaştırııması. Kolon Rektum Hasatlıkları Dergisi.2015; 25(1):SB-04

25. Mohiuddin M, Hayne M, Regine WF, Hanna N, Hagihara PF, McGrath $P$, Marks GM. Prognostic significance of postchemoradiation stage following preoperative chemotherapy and radiation for advanced/recurrent rectal cancers. Int J Radiat Oncol Biol Phys. 2000;48(4):1075-80. 26. Kuzu MA, Demirkıran MA. Kolon Kanserinin Küratif Cerrahi Tedavisi. Alemdaroğlu K, Akçal T, Buğra D (Edit.) Kolon, Rektum ve Anal Bölge Hastalıkları. 2.ci Baskı 395-412, Türk Kolon ve Rektum Cerrahisi Derneği Yayını, İstanbul, 2004 